症例

マンモトーム生検にて診断した肉芽腫性乳腺炎の 2 例

甲南病院外科

原田直樹宮下勝金英植

佐溝政広塚本好彦

肉芽腫性乳腺炎 (granulomatous lobular mastitis) は，乳腺原発の肉芽腫性病変の一 つで稀な疾患とされる.腫瘤を形成し、しばしば乳癌との鑑別が重要になることがある. 症例 1 は 11 歳, 女性. 平成14年12月頃に左乳房腫㿔を自覚し, 近医で精查施行されるも, 確定診断に至らず, マンモトーム生検を希望して平成17年 3 月当院を受診した。左 C 領 域に大きさ $20 \times 15 \mathrm{~mm}$ 大，連珠型の弾性硬の腫瘤として触知された．既往歴として不妊 治療にて胎盤性性腺刺激ホルモン,下垂体性刺激ホルモン, Gn-RH 誘導体等のホルモン 療法薬を投与されていた。平成16年て月，超音波ガイド下マンモトーム生検を施行。組 織は巨細胞と周囲の類上皮細胞を伴った肉芽形成がられ肉芽腫性乳腺炎と診断され 太. 診断後 2 年経過しているが，再発することなく現在経過観察中である. 症例 2 は51 歳, 女性. 平成18年 2 月乳癌满診にてマンモグラフィーで異常を指摘された。超音波, 造影 CT, 穿刺吸引細胞診を施行されるも確定診断が得られずマンモトーム生検を施行 した．症例 1 と同様の組織結果であり肉芽腫性乳腺炎と診断された。

索引用語：マンモトーム, 肉芽腫性乳腺炎, 乳腺腫場

\section{緒 言}

Granulomatous lobular mastitis (肉芽腫性乳腺炎) は1972年 Kessler と Wollochにより提唱された炎症 性乳腺疾患の一つで，経産婦にみられるときれる比較 的稀な疾患である。臨床上極めて乳癌と紛らわしい症 状を呈すことが多く，その鑑別が問題となる. 今回超 音波ガイド下マンモトームにて診断可能であった未産 婦の肉芽腫性乳腺炎の 2 例を経験したので報告する。

\section{症 例}

症例 $1: 41$ 歳, 女性.

主訴: 左乳房腫瘤.

既往歴：平成 12 年 5 月より平成 16 年 3 月まで不姓治 療にて胎盤性性腺刺激ホルモン, 下垂体性刺激ホルモ ン, Gn-RH 誘導体等のホルモン療法薬在投与. 出産歷 なし.

現病歴：平成14年12月頃に左乳房腫瘤を自覚し近医 受診, マンモグラフィ，超音波，MRI，穿刺吸引細胞

2006年 6 月 26 日受付 2006 年 $\times$ 月 4 日採用

\section{〈所属施設住所〉}

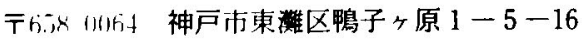

診, 針生検が行われた。生検の結果, 一つは脂肪壊死, 一つは class III と言われ経過観察されていたが, 今回 マンモトーム生検を希望して当院を受診した。

現症：左C領域に大きさ $18 \times 15 \mathrm{~mm}$ 大の連珠型, 弾 性硬, 境界明暸, 可動良好な腫瘤触知された。他に左 AC 領域に $20 \times 15 \mathrm{~mm}$ 大，弾性硬な同様の腫瘤が触知 された。腋窝リンパ節は触知されず。

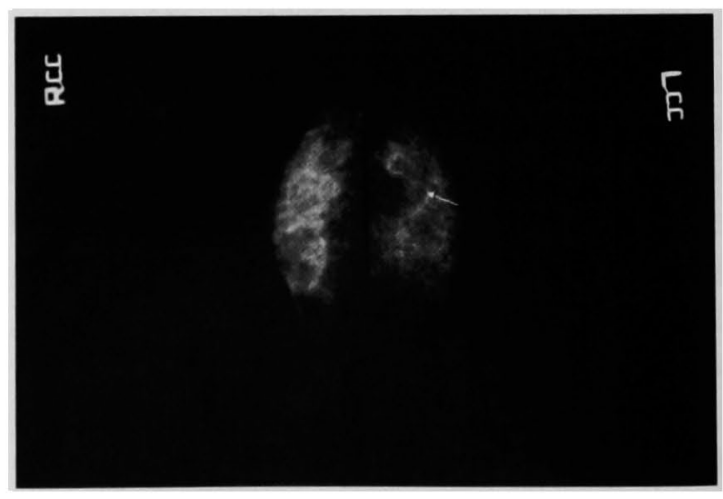

图 1 マンモグラフィ: 左乳腺に非対称性の潇築の乱れ が確認さ机 ( $\rightarrow)$, カテコリー3 と診断した。 

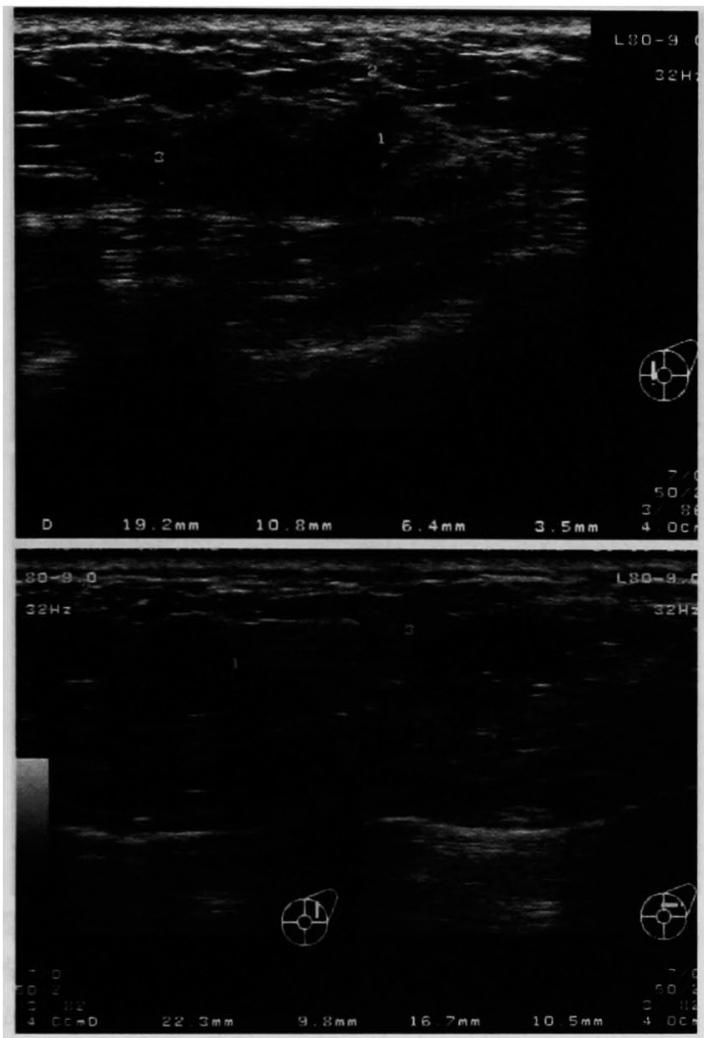

図 2 乳腺超音波所見：左 $\mathrm{A}$ に最大 $21 \mathrm{~mm}$ の八つ頭状 の不整形の hypoechoic mass ( a ), C 領域に同様の不 整な連珠状の腫煌 (b). 共に内部エコーは粗で境界エ コーも不均一, 後方エコーはわずかに増強を認める。

$\frac{a}{b}$

マンモグラフィ:左乳腺に非対称性の構築の乱れが 確認され（図 1)，カテゴリー3 と診断した。

乳腺超音波所見：左 $\mathrm{A} に$ 最大 $21 \mathrm{~mm} の 八 つ$ 頭状の 不整形の hypoechoic mass, および C 領域に同様の不 整な連珠状の腫愓が碓認され，共に内部エコーは粗で 境界エコーは不均一で，後方エコーのわずかの増強を 認めた（図 2)。悪性を疑い，穿刺吸引細胞診も再検し たが検体不適であり，平成17年 7 月マンモトーム生検 を施行した。

マンモトーム捺印細胞診：マクロファージ，多角の 巨細胞，好中球のような炎症細胞そして線維芽細胞が みられており乳腺の上皮成分はほとんどみられなかっ た(图3).

病理組織学的所見：巨細胞と周囲の類上皮細胞を伴 った肉芽形成がみられ慢性炎症をうかがわせる，乳管

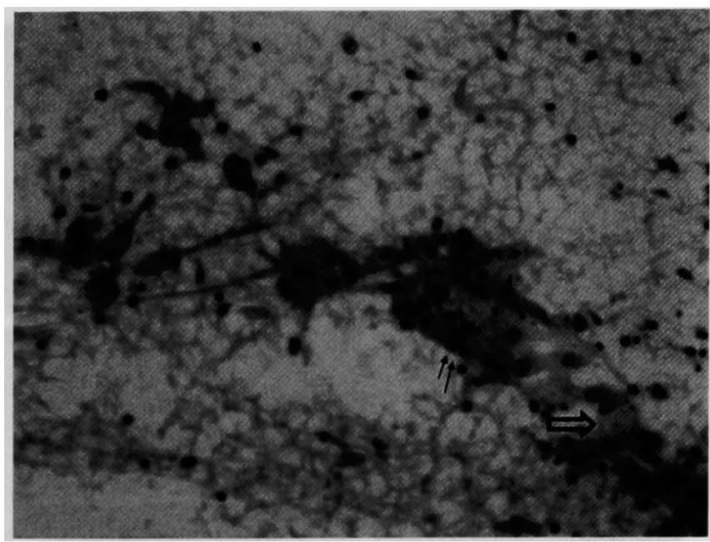

図3細胞診 (マンモトーム捺印) Papanicolaou $\times 20$ ): マクロファージ ( $\Leftrightarrow)$, 多角の巨細胞 $(\rightarrow)$ がみられて おり乳腺の上皮成分はほとんどみられなかった。

の周囲にリンパ球の浸潤ともなった間質の増殖により 乳管がいびつになり拡張もみられ，リンパ球主体の慢 性炎症像が乳管よりもさらに散在的に抹消性, 小葉中 心性に認められた（図 4).

以上の結果より肉芽腫性乳腺炎と診断された。現在 は不妊治療も行っておらず, 経過観察を行っているが 腫場の増大傾向はみられていない.

症例 $2: 51$ 歳, 女性.

主訴: 左乳腺画像異常陰影.

現病歴：平成18年 2月乳癌検診にてマンモグラフィ で異常を指摘された。超音波, 造影 CT, 穿刺吸引細胞 診を施行されるも確定診断得られずマンモトーム生検 の適応となった。

既往歴：糖尿病にて 1 年前より内服加療中.

現症：左 BA 領域に $28 \mathrm{~mm} \times 25 \mathrm{~mm}$ 大の弾性硬, 表 面平滑, 境界明瞭, 可動性良好な腫湯を触知された, 左乳頭の宿没所見が見られた。腋窝リンパ節は触知さ れず。

マンモグラフィ：左乳腺に2 $4 \times 20 \mathrm{~mm}$ 大の境界不明 瞭な腫瘤が確認され,カテゴリー4と診断した(図 5).

乳腺超音波所見：左 B に共に最大 $7.5 \mathrm{~mm} の$ hypoechoic mass が 2 個認められた。両者間には連続してい ることをうかがわせる拡張乳管がみられた。内側の mass は形状不整て境界不明膫, high echo spot を伴い 後方エコーは減弱していた(図6 a)。もう一方の腫瘍 は, 形状整, 境界明瞭, 内部エコー均一, 後方エコー は不変であった(図6 b). また, 両者とも内部血流は 確認されなかった。 


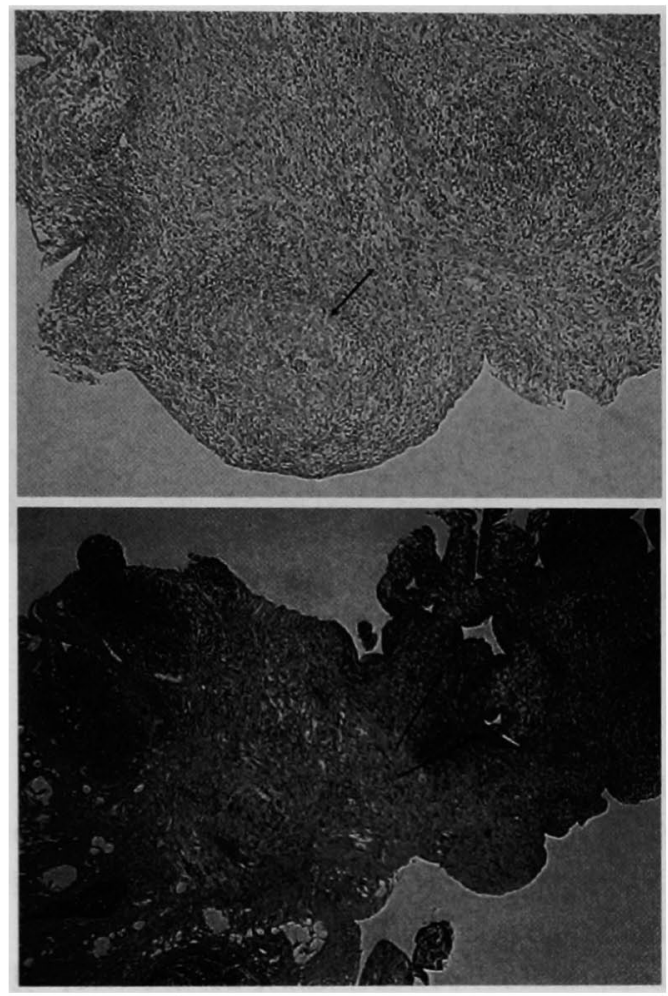

図 4 病理組織学的所見：a）巨細胞を伴う肉芽腫 $(\rightarrow)$ を認める (H.E 染色×10)． b) リンパ浸潤 伴った間質の增殖といびつな乳管 $(\rightarrow)$ (H.E染 色×111。 $\frac{a}{b}$

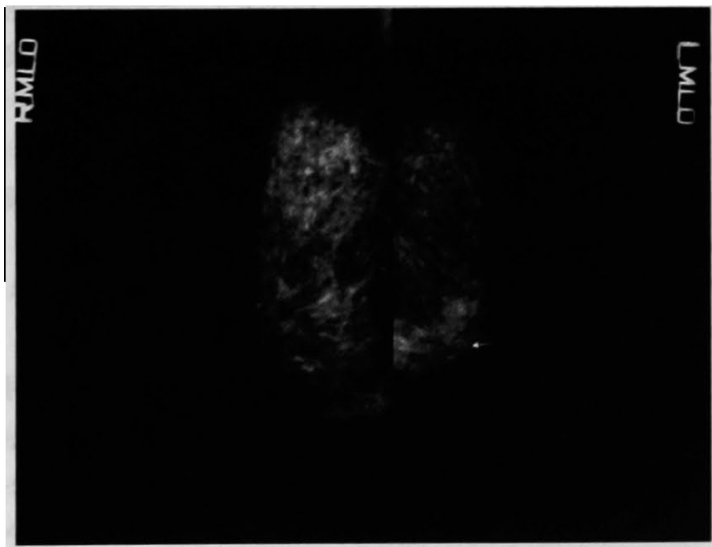

図 5 マンモグラフィ：左乳腺に境界不明瞭な腫烧陰影 (矢印).カテコリー4 と診断した。

エコー上は悪性疾患を疑い，穿刺吸引細胞診も再検 したが検体不適であった。

乳腺造影 CT : 左 B 領域に $8 \mathrm{~mm}$ 大の小結節の集簇
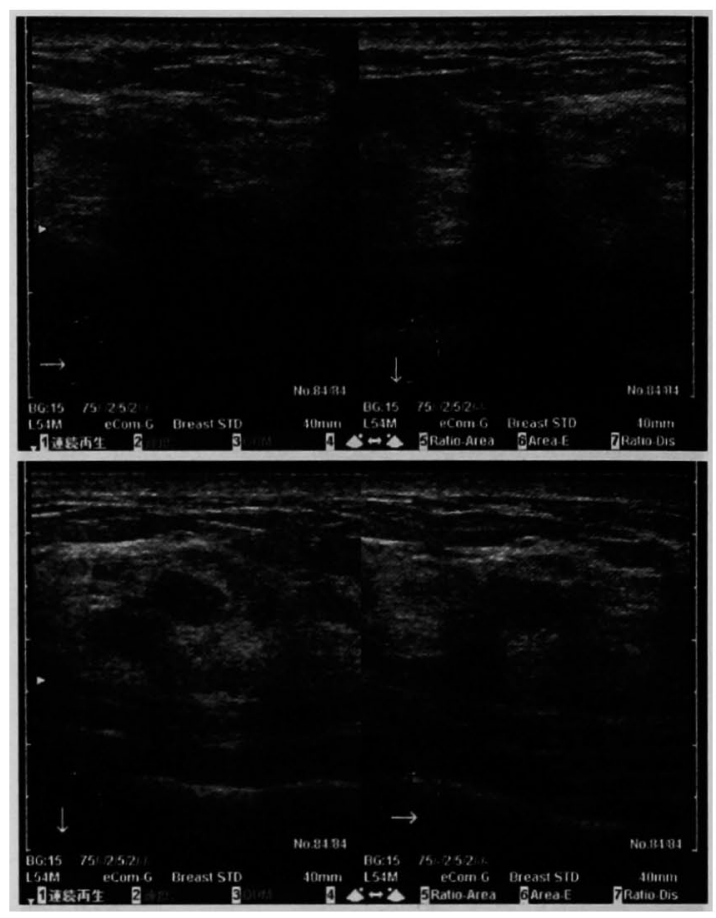

図6 乳腺超音波所見：左 Bに共に最大 $7.5 \mathrm{~mm}$ の hypoechoic massが 2 個認められた。両者間には連続 していることをうかがわせる拡張乳管がみられた。内 側の mass は形状不整で境界不明眭, hige echo spotを 伴い後方エコーは隇弱（a）。もう一方の腫瘍は，形状 整, 境界明暸, 内部エコー均一, 後方エコ一は不変 (b).

$\frac{a}{b}$

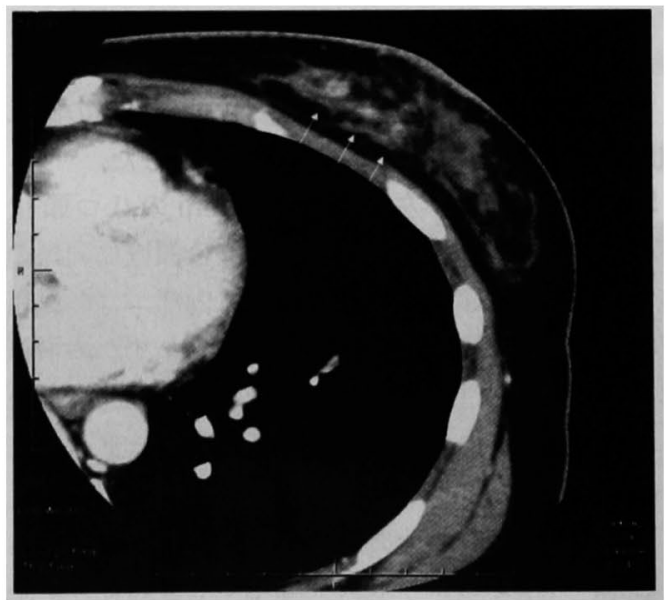

図 7 叱腺造影 CT：左 B 領域に $8 \mathrm{~mm}$ 大の小結節 の集簇様病変 (知印) 認める。不均一に造影され i. 

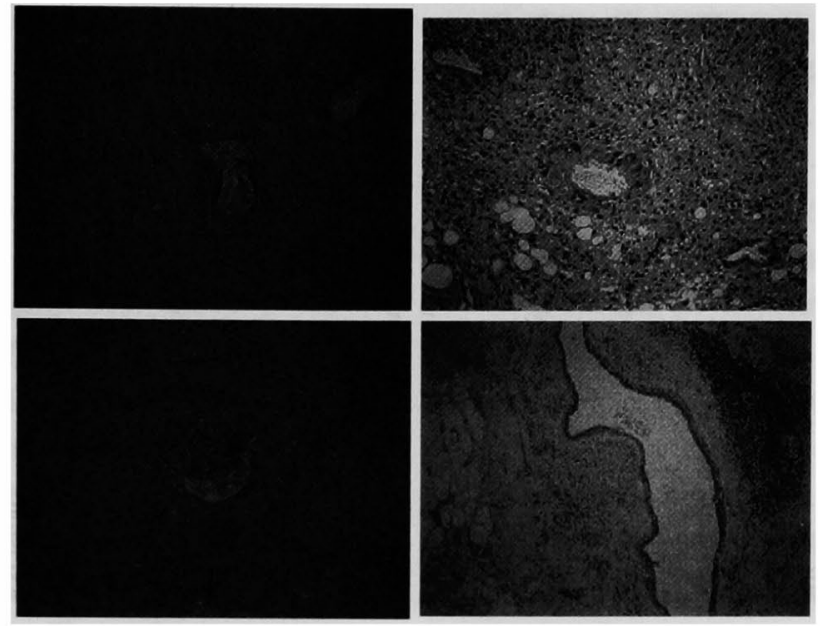

図 8 病理組織学的所見：a）萎縮した末梢乳管の周囲に類上皮 細胞伴う肉芽腫性变化 $(H . E$ 染色 $\times 20)$. b ) 巨細胞 (H.E 染色 $\times$ 20). c) 多角細胞 (H.E染色 $\times 20)$. d) 中枢側の拡張した乳 管, 周囲は炎症細胞のみ (H.E 染色 $\times 4)$.

$$
\begin{array}{l|l}
a & b \\
\hline c & d
\end{array}
$$

椂病変を認めた。不均一に造影された(図7)。細胞診 を行ったが検体不適であり，平成18年 4 月マンモトー 么生検を施行した。

病理組織学的所見：症例 1 同様に萎縮した末梢乳管 の周囲に類上皮細胞や，巨細胞，多角細胞が確認され る.また, 中枢側の乳管周囲は炎症細胞のみであった (図 8).

\section{考 察}

肉芽腫性乳腺炎は1972年に Kesseler とWolloch" により報告された乳腺の腫溜形成性炎症性疾患であ る. 通常片側性に孤立性の腫瘤が出現し, しばしば腋 窩リンパ腫大も伴うため乳癌との鑑別が重要になる。 ほとんどの症例が経産婦に出現し122, 出産や自己免疫 の関与3が指摘されているが詳細は不明である．本邦

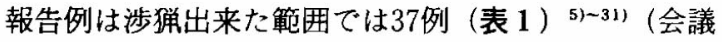
録除く)であり，稀な疾患であると考えられる．比較 的若年発症が多いとされでおり, 本邦での発症年齢 は26歳〜75歳 (平均 $40 \pm 12.19$ 歳)であった。出産歷の ない症例は記載のあった 16 例中, 自験例を含めた 3 例 に認めた。 また，明らかにホルモン郕投与の既往があ つた症例は 2 例，結節性紅斑やリウマチ所見などの自 己免疫性疾患との関連を示唆する全身の臨床症状を伴 っていた症例は 4 例にみられた。乳腺切除を施行され たものが 6 例で，そのうち, 穿刺吸引細胞診で Class IV 以上の症例は 3 例であった。細胞診で本疾患を示唆し
た症例も 2 例存在した。自験例では 2 例共に末産婦で あったが, 症例 1 ではホルモン補充療法を施行されて おり因果関係も示唆された。一方，症例 2 では未産婦 であり，楉尿病の治療以外の既往はなかった，画像検 查においては，マンモグラフィでは高吸収の腫瘤陰影 として認められ，境界不鮮明な場合が多く，石灰化像 が認められるものは少ないとされ目験例も同様で あった。 また，超音波検査では不整形の低エコー結節 として描出され, 内部には高輝度エコー像はあまりな く, 後方エコーは不変か減弱することが多い5) とされ ているが，本症例では 1 例目は後方エコーのわずかな 増強を認め, 2 例目では内部に高輝度の echoogenic spot が確認されている．2例とも連珠様あるいは多発 性のエコー像が確認され, Matsumoto ${ }^{6} や$ 住吉 $^{7}$ らの報 告とも一致しており，乳管内進展を伴った乳癌や多発 癌》との鑑別が必要となることもあると考えられる。 画像診断上は, 諸家 ${ }^{5 / 8)}$ の報告同様, 乳癌との鑑別は困 難であろうと考えられた。細胞診では，多核白血球の 多い炎症性背景に, 類上皮細胞や多核巨細胞が出現す るなどの特徵的な所見を有するため, 上皮性悪性腫場 との鑑別も可能9との報告あるが，本邦でもほほ全例 に組織診断が用いられており，確定診断には組織診が 必須であると思われる ${ }^{10)}$. 組織学的には乳腺小葉中心 性に Langhans 巨細胞を伴う類上皮細胞よりなる肉芽 腫を特徵とし,炎症の程度により小葉構造は失われる。 


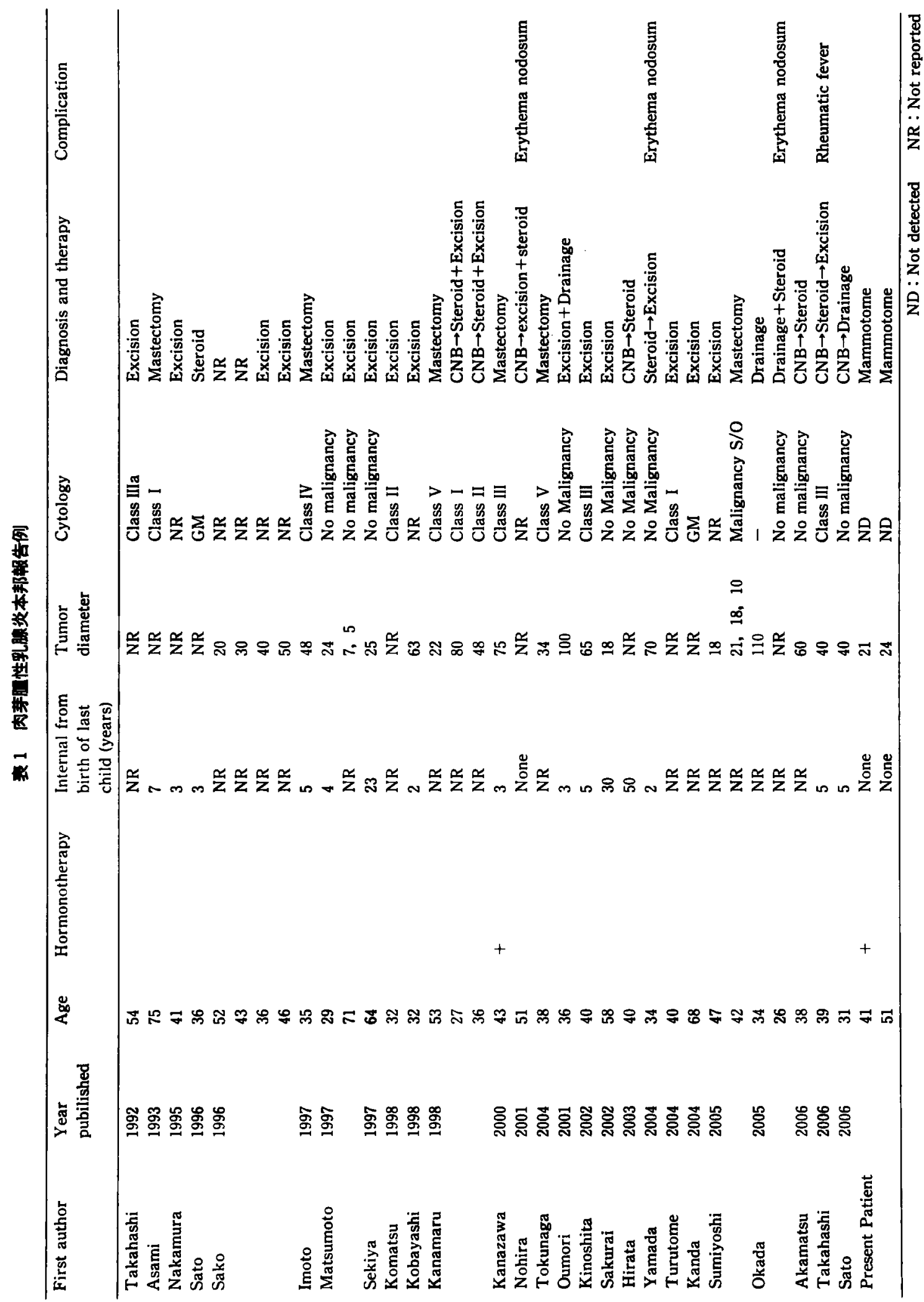


また，乾酪壊死，真菌あるいは異物等は認めず，血管 炎や乳管㹡張も伴わない，他に乳腺にみられる類上皮 細胞肉芽腫形成病変としては結核, サルコイドーシス, 真菌症などが挙げられる432)がいずれも稀な疾患であ る. 従来では外科生㭘をか机て，肉芽腫組織を完全に 切除するケースが多かったが, 切除することで創感染 の可能性もあり ${ }^{33)}$, 鑑別診断がついた場合ステロイド 療法による非侵襲的な治療を(1133)優先するべきである と考えられる．ただ，乳腺炎の悪化により乳腺が広範

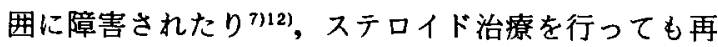
発する症例もある(1035)。 また，ステロイドの投与方 法 ${ }^{1113334)}$ に関しても一定の見解は得られておらず，今 後の症例の蓄積が必要であると考えられる。

\section{結 語}

マンモトーム生検にて診断した, 稀な疾患であると される肉芽腫性乳腺炎の 2 例を経験した，小葉が障害 される原因不明な肉芽腫性炎症で, 乳癌との鑑別が重 要であるが，低侵襲であるマンモトーム生検は確定診 断に有用な手段であった。

\section{文 献}

1) Kesseler E, Wolloch $Y$ : Granulomatous mastitis : A lesion clinically stimulating carcinoma. Am J Clin Pathol 58:642-646, 1972

2) Al Nazer MA: Idiopathic granulomatous lobular mastitis. A forgotten clinical diagnosis. Saudi Med J 24 : 1377-1380, 2003

3) Brown KL, Tang PHL : Postlactational tumoral granulomatous mastitis : a localized immune phenomenon. Am J Surg 138:326-329, 1979

4) Rosen PP, Obernman HA : Tumor of the mammary gland. Atlas of tumor Pathology third series. Armed Forces Institute of Pathology Washington DC, 1993, p23-47

5）小松誠，浜木綿子，小松倰雄地：肉芽腫性乳腺 炎の 1 例。乳澏の臨 $13: 390-392,1998$

6) Matsumoto $\mathrm{H}$, Iino $\mathrm{Y}$. Takei $\mathrm{H}$, et al : Chronic mastitis clinically similar to breast carcinoma : A report of two cases. Kitakanto Med J 47 : 449-451, 1997

7) 住吉一浩, 芝山雄老, 野原丈裕他：肉芽腫性乳腺 炎の 2 例. 大阪医大誌 $64: 45-51 ， 2005$

8）高橋弘昌, 本郷友徳, 佐々木文章他: 乳癌と鑑別 を要した慢性肉芽腫性乳腺炎の1例。乳癌の臨 $7: 637-642,1992$
9）赤松 節，姫路由香里，長澤優子他：肉芽腫性乳 腺炎の 1 例。日臨細胞誌 $45: 32-34 ， 2006$

10）佐藤耕一郎，加藤丈人，佐藤 孝他：手術後の病 理㭘索にて確定診断された肉芽腫性乳腺炎の 1 例。日臨外会誌 $67: 759-762,2006$

11）金丸 仁，横山日出太郎，小池 誠他：乳癌との 鑑別に難浩した難治性肉芽腫性乳腺炎の 3 例。乳 癌の臨 $13: 393-398,1998$

12）岡田憲三, 井上 石, 杉下博基他：肉芽腫性乳腺 炎に対するSeton 法の有用性. 乳癌の臨 20 ： 393-398, 2005

13）高橋吉徳, 竹花 教, 遠藤義洋他：肉芽腫性乳腺 炎の 1 例. 外科治療 $94: 347-349,2006$

14）神田真規，上田 恵，木村 友他：肉芽腫性乳腺 炎の 1 例.日臨細胞会広島会報 $25: 52-55,2004$

15）鶴留貴子, 磯本一郎, 林 邦昭他：肉芽腫性乳腺 炎の 1 例. 臨放 $49: 933-936,2004$

16）山田陽三，足立厚子：肉芽腫性乳腺炎に伴った結 節性紅斑のI 例. 皮膚臨床 $46: 1033-1036,2004$

17）木下智樹，岩本 整，鳴海 康他：炎症性乳癌と の鑑別を要した肉芽腫性乳腺炎. 乳癌の蹦 17 ： $69-73,2002$

18）大森浩志，三瓶訓子，小池 誠他：乳癌との鑑別 に難涉した難治性肉芽腫性乳腺炎の 1 例。乳癌の 臨 $16: 611-616,2001$

19）野平元備，䃆持 淳，新海 法他：肉芽腫性乳腺 炎に伴った結節性紅斑の 1 例。日皮会誌 111 ： $2119-2124,2001$

20）吉田清香, 大竹 徹, 伊藤 淳他：乳癌として診 断, 治療された granulomatous lobular mastitis の 1 例. 福島医誌 $53: 355-359,2003$

21) Hirata $S$, Saito $T$, Kiyanagi $K$, et al : Granulomatous Mastitis Diagnosed by CoreNeedle Biopsy and Successfully Treated with Corticosteroid Therapy: A Case Report. Breast Cancer $10: 378-381,2003$

22) Sakurai T, Oura $S$, Tanino H, et al : A Case of Granulomatous Mastitis Mimicking Breast Carcinoma. Breast Cancer $9: 265-268,2002$

23) Tokunaga $E$, Kimura $Y$, Kitamura $K$, et al: Granulomatous lobular mastitis misdiagnosed as breast carcinoma. Breast $\mathrm{J} 10: 261-262$, 2004

24) Kobayashi $T K$, Sugihara $H$, Kato $M$, et al: 
Cytologic features of granulomatous mastitis. Report of a case with fine needle aspiration cytology and immunocytochemical findings. Acta Cytol 42 : 716 -720, 1998

25) Imoto $S$, Kitaya $T$, Kodama $T$, et al : Idiopathic granulomatous mastitis: case report and review of the literature. Jpn J Clin Oncol 27 : 274-277, 1997

26）関屋順子, 矢野浩司, 高村常子他：肉芽腫性乳腺 炎の 1 例. 日臨細胞会九州会誌 $28: 37-40,1997$

27）迫 裕孝, 沖野功次, 阿部 元他：外来にて生㛟 を施行した乳房腫觢の臨床病理学的検討．滋賀医 大誌 $11: 17-25,1996$

28）㳀見恵司：胃密を合併した肉芽腫性乳腺炎の1 例. 日臨外会誌 $54: 89-94,1993$

29) Sato $N$, Yamashita $H$, Kozaki $N$, et al: Granulomatous mastitis diagnosed and followed up by fine-needle aspiration cytology, and successfully treated by corticosteroid therapy : Report of a case. Jpn J Surg 26 : 730-733, 1996

30）中村雅哉, 柏瀨芳久，須永義市 他：肉芽䭪性乳腺 炎の 1 例. 日臨細胞会誌 $34: 482-484,1995$

31) Kanazawa $S$, Nagae $T$, Fukuda $K$, et al: Granulomatous lobular mastitis: difficulty of diagnosis. Int J Clin Oncol 5:57-61, 2000

32）渡辺騏七郎 : Granulomatous lobular mastitis \& Plasma cell mastitis.病理と臨 $19: 352-354$, 2001

33) Harris JR: Disease of the breast. 2nd ed., Lippincott Williams \& Wilkins, Philadelphia, 2000, p47-55

34) Cohen $C$ : Granulomatous mastitis. A review of 5 cases. S Air Med J $52: 14-16,1977$

35) Hughes LE : Non-lactonal inflammation and duct ectasia. Br Med Bull $47: 272-283,1991$

\title{
TWO CASES OF GRANULOMATOUS LOBULAR MASTITIS DIAGNOSED BY MAMMOTOME BIOPSY
}

\author{
Naoki HARADA, Masaru MIYASHITA, Yongsik KIM, \\ Masahiro SAMIZO and Yoshihiko TSUKAMOTO \\ Department of Surgery, Kohnan Hospital
}

Granulomatous lobular mastitis is a rare benign tumor and very difficult to differentiate from breast cancer. We report two cases of granulomatous lobular mastitis which were diagnosed by mammotome biopsy.

Case 1: A 41-year-old woman was admitted because of two left breast tumors. One tumor was $18 \times$ $15 \mathrm{~mm}$ in size and located in $\mathrm{C}$ region of the breast, and the other was $20 \times 15 \mathrm{~mm}$ in size, located in the $\mathrm{AC}$ region, and suspected to be breast cancer.

Case 2: A 51-year-old woman was admitted because of an abnormal shadow on mammography. A tumor was $28 \mathrm{~mm} \times 25 \mathrm{~mm}$ in size, located in the BA region of the breast, and suspected to be breast cancer.

In both cases, the tumors were unable to be diagnosed by aspiration biopsy cytology, so mammotome biopsy under ultrasonic scans was performed. The histopathological diagnosis was granulomatous lobular mastitis of the breast without malignancy. 